\title{
Assessment of Early Growth Performance of Melia dubia Cav. Clones
}

\author{
H. Nayana*, Ashok B. Divatar, V. Maheswarappa, G. N. Hosagoudar and Ganapathi \\ Department of Silviculture and Agroforestry, College of Forestry, Ponnampet University of \\ Agricultural and Horticultural sciences, Shivamogga, Karnataka, India \\ *Corresponding author
}

\section{A B S T R A C T}

\section{Keywords}

Melia dubia, Plywood, Clones, Industries

\section{Article Info}

Accepted:

20 December 2020

Available Online:

10 January 2021
Clonal forestry has a remarkable contribution for paper, packaging, tissue paper, paperboard, plywood, veneer industries, etc., for which wood is being used as a raw material. Industrial agroforestry with the fast-growing species viz., poplar, eucalyptus, willow, leucaena, casuarina, bamboo and Malabar neem can be grown commercially in private lands as suitable species for raw materials in many wood based industries. Among these species, M. dubia (Malabar neem) is an indigenous tree species belongs to family Meliaceae that has emerged as a suitable raw material due to its increased pulp recovery and exceptional strength. The timber is ideal for plywood manufacture at commercial scale Thus in the present study, the early growth performance of $M$. dubia clones was conducted at the main agricultural and horticultural research station, Iruvakki, Sagara (taluka), Shivamogga (district), Karnataka. Ten M. dubia clones were planted in RCBD design with the spacing of $4 \mathrm{~m} \times 4 \mathrm{~m}$ in five replications. The observations on total height and collar diameter were recorded up to 9 months. The significant difference was observed for height and collar diameter of different $M$. dubia clones. Considerable height was recorded in clone IFGTBC10 and IFGTBC8 $(269.70 \mathrm{~cm}$ and $233.56 \mathrm{~cm}$ respectively). substantial collar diameter was recorded in clone IFGTBC8 and IFGTBC10 $(1.79 \mathrm{~cm}$ and $1.71 \mathrm{~cm}$ respectively). Substantial volume index was recorded in clone IFGTBC10 $\left(799.70 \mathrm{~cm}^{3}\right)$ at nine months after planting.

\section{Introduction}

Clonal forestry has a significant contribution in industries like paper, packaging, tissue, paperboard, plywood, veneer, etc., which uses wood as a raw material. Industrial agroforestry plantations with the fast-growing tree species such as Poplar, Eucalyptus, Willow, Leucaena, Casuarina, Bamboo and Melia are the ideal species that can be grown commercially in private lands. The 33 per cent of round wood around the world comes from plantations of fast-growing trees from only 5-7 per cent area. The proportions of plantations in Asian countries around India has increased substantially in the last two decades than other continents and simultaneously focus on utilization changing from the long rotation to short-rotation trees. In India, more than 90 per cent of industrial round wood comes from fast-growing species growing outside forests. The pulp yield from 
these species ranged from 40 to 49 per cent of the wood biomass (Prasad et al., 2009).

M. dubia Cav. commonly known as Malabar neem, is a member of the family Meliaceae. It is an industrially and economically important fast growing multipurpose tree species, which can be harvested on a short rotation. Still, large scale planting is hampered due to poor seed germination (Tilakaratna, 1991). It is an important alternative timber species and has been realized for use in operational planting to fulfilthe requirement for timber, pulp, biomass and source of plywood (Nasayao et al., 1993). It is a fast growing tree used for afforestation and land rehabilitation (Langenberger et al., 2005). M. dubia is an important indigenous multipurpose fast growing species tree species grown commercially under various afforestation schemes for fodder, timber and industrial woods. It is amenable for the pulp and paper industry due to superior pulp yield as well as quality (Sharma et al., 2019b).

M. dubia has emerged as a suitable raw material because of its increased pulp recovery and exceptional strength. Pulp recovery was recorded at 50 per cent, which is higher than that of Eucalyptus and Acacia. Similarly, the Kappa number (used to assess bleachability) was less than 20, which is excellent as compared with the traditional raw material (Parthiban et al., 2009).

M. dubia is valued for its high-quality termite and fungus resistant timber (Suprapti et al., 2004). Its branches are used as fuelwood, termite resistant poles and leaf as a fodder. The timber is mainly used for furniture, agricultural implements and house construction.

M. dubia has decorative appearances, which is making it suitable for furniture making (Mandang and Artistien, 2003). In Ceylon, it is used for the outriggers of the boats. In Java and Sumatra for the interiors of houses and it is much in demand for uprights of buildings in Tonkin. The timber of M. dubia is found to be ideal for plywood manufacture. It has been identified as one of the important species for the production of plywood on a commercial scale.

Considering the importance and uses of Melia, in recent years, early evaluations of different clones are required for the Malnad region, especially for Agroforestry practices. Hence, the experiment was laid out to assess the early growth performance of $M$. dubia clones.

\section{Materials and Methods}

The present investigation was undertaken to study the early growth performance of Melia dubia Cav. clones. at Main Agricultural and Horticultural Research Station (MAHRS), Iruvakki, Sagara (taluka), Shivamogga (district), Karnataka (Table 1).

\section{Genetic material}

Ten $M$. dubia clones were procured from the Institute of Forest Genetics and Tree Breeding (IFGTB), Coimbatore (Table 2).

\section{Details of the experiment}

M. dubia clones considered as ten different treatments which were randomly planted in five replications with a spacing of $4 \mathrm{~m} \mathrm{x} 4 \mathrm{~m}$ with five ramets per clone for each replication in a randomized complete block design.

\section{Observations}

The survival per cent and quantitative traits like collar diameter and total height were taken for each clone at every three months interval upto nine months after planting. 
Survival rate: Survival rate (\%) was calculated by considering the number of plants survived after nine months of planting to the number of plants planted.

Survival rate $=\frac{\text { No. of plants survived }}{\text { No. of plants planted }}$ X100

Total height (cm): The total height of the clones was measured from base to the tip of the leading stem by using measuring tape.

Collar diameter (mm): The collardiameter of the clones was measured by using a digital Vernier calliper. Measurements were taken at the base region, i.e. $5 \mathrm{~cm}$ above the soil surface.

Volume index $\left(\mathrm{cm}^{3}\right)$ : Volume index of individual clones were calculated by using following formula

Volume index $=\mathrm{d}^{2} \mathrm{xh}$

Where, $\mathrm{d}=$ Collar diameter $(\mathrm{mm}), \mathrm{h}=$ Height (cm)

Statistical analysis: Data on growth parameters (collar diameter and height) were subjected to ANOVA analysis using a randomized complete block design (SPSS software).

\section{Results and Discussion}

In this experiment, 100 per cent survival rate was observed among different clones.

\section{Total height of Melia dubia clones at} different intervals after planting

The mean values for the total height are presented in Table 3. Height growth of $M$. dubia clones varied significantly at the time of planting. Among the different clones, maximum height was recorded in clone
IFGTBC10 $(46.60 \mathrm{~cm})$, minimum height was found in IFGTBC16 $(30.24 \mathrm{~cm})$. Three months after planting clone IFGTBC10 $(48.07 \mathrm{~cm})$ recorded the highest value for height and clone IFGTBC16 had the least height $(30.97 \mathrm{~cm})$. Six months after planting the height growth of the clone IFGTBC8 $(72.04 \mathrm{~cm})$ was significantly superior over all other clones, clone IFGTBC1 $(55.81 \mathrm{~cm})$ had the least height. Nine months after planting the maximum height was recorded in the IFGTBC10 $(269.70 \mathrm{~cm})$, whereas the minimum height was recorded in the IFGTBC4 $(180.26 \mathrm{~cm})$.

\section{Collar diameter of Melia dubia clones at different intervals after planting}

The mean values for the collar diameter are presented in Table 4. At the time of planting significantly highest collar diameter was recorded for the IFGTBC10 $(0.65 \mathrm{~cm})$, whereas the IFGTBC1 $(0.53 \mathrm{~cm})$ was recorded the less value compared to all other clones. Three months after planting maximum collar diameter was observed in the clone IFGTBC8 $(0.75 \mathrm{~cm})$, where as least value was found in IFGTBC12 and IFGTBC14 $(0.68 \mathrm{~cm}$ and $0.68 \mathrm{~cm})$. Six months after planting the collar diameter of the clones did not differ significantly. The maximum collar diameter was observed in the IFGTBC10 $(1.33 \mathrm{~cm})$, whereas the least value was found in the IFGTBC1 $(1.11 \mathrm{~cm})$. Nine months after planting the maximum collar diameter was recorded for IFGTBC8 $(1.79 \mathrm{~cm})$. Whereas, minimum collar diameter was recorded in clone IFGTBC12 $(1.43 \mathrm{~cm})$.

\section{Volume index of Melia dubia clones at different intervals after planting}

The mean values for the volume index are presented in Table 5. At the time of planting maximum value for volume index was recorded in IFGTBC10 $\left(20.17 \mathrm{~cm}^{3}\right)$, whereas 
the IFGTBC1 $\left(9.56 \mathrm{~cm}^{3}\right)$ was recorded minimum value for volume index. Three months after planting clone IFGTBC8 (27.07 $\mathrm{cm}^{3}$ ) recorded the maximum value for volume index, where as least value was recorded in the IFGTBC14 $\left(16.35 \mathrm{~cm}^{3}\right)$.

Table.1 Location details of the clonal trials

\begin{tabular}{|c|l|c|}
\hline Sl. No & \multicolumn{2}{|c|}{ Details } \\
\hline $\mathbf{1}$ & Latitude & $14^{\circ} 05^{\prime} 51.261 " \mathrm{~N}$ \\
\hline $\mathbf{2}$ & Longitude & $75^{\circ} 18^{\prime} 33.714^{\prime \prime} \mathrm{E}$ \\
\hline $\mathbf{3}$ & Altitude $(\mathrm{m})$ & 650 \\
\hline $\mathbf{4}$ & Mean annual rainfall $(\mathrm{mm})$ & $2000 \mathrm{~mm}$ \\
\hline $\mathbf{5}$ & Mean maximum temperature $\left({ }^{\circ} \mathrm{C}\right)$ & $31.2^{\circ} \mathrm{C}$ \\
\hline $\mathbf{6}$ & Mean minimum temperature $\left({ }^{\circ} \mathrm{C}\right)$ & $18.96^{\circ} \mathrm{C}$ \\
\hline $\mathbf{7}$ & Soil type & Dark red with clay loam texture \\
\hline
\end{tabular}

Table.2 Clonal details of Melia dubia

\begin{tabular}{|c|c|c|}
\hline Sl. No. & Treatments & Clones \\
\hline 1 & T1 & IFGTBC1 \\
\hline 2 & T2 & IFGTBC3 \\
\hline 3 & T3 & IFGTBC4 \\
\hline 4 & T4 & IFGTBC5 \\
\hline 5 & T5 & IFGTBC6 \\
\hline 6 & T6 & IFGTBC8 \\
\hline 7 & T7 & IFGTBC10 \\
\hline 8 & T8 & IFGTBC12 \\
\hline 9 & T9 & IFGTBC14 \\
\hline 10 & T10 & IFGTBC16 \\
\hline
\end{tabular}

Table.3 Height of Melia dubia clones at different intervals after planting

\begin{tabular}{|c|c|c|c|c|}
\hline \multirow[t]{2}{*}{ Clones } & \multicolumn{4}{|c|}{ Height $(\mathbf{c m})$} \\
\hline & At the time of planting & 3 MAP & 6 MAP & 9 MAP \\
\hline IFGTBC1 & $32.56^{\mathrm{a}}$ & $35.25^{\mathrm{a}}$ & $55.81^{\mathrm{a}}$ & $198.83^{\mathrm{ab}}$ \\
\hline IFGTBC3 & $39.20^{\mathrm{b}}$ & $41.21^{\mathrm{b}}$ & $64.56^{\mathrm{abc}}$ & $204.20^{\mathrm{b}}$ \\
\hline IFGTBC4 & $32.16^{\mathrm{a}}$ & $33.41^{\mathrm{a}}$ & $59.90^{\mathrm{ab}}$ & $180.26^{\mathrm{a}}$ \\
\hline IFGTBC5 & $31.86^{\mathrm{a}}$ & $36.28^{\mathrm{a}}$ & $65.58^{\mathrm{bc}}$ & $182.60^{\mathrm{ab}}$ \\
\hline IFGTBC6 & $41.76^{b}$ & $42.13^{\mathrm{bc}}$ & $66.43^{\mathrm{bc}}$ & $194.90^{\mathrm{ab}}$ \\
\hline IFGTBC8 & $43.56^{\mathrm{bc}}$ & $47.07^{\mathrm{cd}}$ & $72.04^{\mathrm{c}}$ & $233.56^{\mathrm{c}}$ \\
\hline IFGTBC10 & $46.60^{c}$ & $48.07^{\mathrm{d}}$ & $68.10^{\mathrm{bc}}$ & $269.70^{d}$ \\
\hline IFGTBC12 & $33.96^{\mathrm{a}}$ & $34.92^{\mathrm{a}}$ & $61.94^{\mathrm{ab}}$ & $196.20^{\mathrm{ab}}$ \\
\hline IFGTBC14 & $31.84^{\mathrm{a}}$ & $35.13^{\mathrm{a}}$ & $62.32^{\mathrm{ab}}$ & $192.80^{\mathrm{ab}}$ \\
\hline IFGTBC16 & $30.24^{\mathrm{a}}$ & $30.97^{\mathrm{a}}$ & $56.03^{\mathrm{a}}$ & $205.70^{\mathrm{ab}}$ \\
\hline Mean & 36.37 & 38.44 & 63.27 & 205.87 \\
\hline SEm $( \pm)$ & 1.53 & 1.77 & 3.22 & 8.19 \\
\hline CD @ 5\% & 5.70 & 4.97 & 9.24 & 22.41 \\
\hline
\end{tabular}

Figures with similar letter/alphabet as superscript do not differ significantly CD- Critical Difference

*MAP- Months After Planting 
Table.4 Collar diameter of Melia dubia clones at different intervals after planting

\begin{tabular}{|c|c|c|c|c|}
\hline \multirow{2}{*}{ Clones } & \multicolumn{4}{|c|}{ Collar diameter (cm) } \\
\cline { 2 - 5 } & $\begin{array}{c}\text { At the time of } \\
\text { planting }\end{array}$ & $\mathbf{3}$ MAP & $\mathbf{6}$ MAP & $\mathbf{9}$ MAP \\
\hline IFGTBC1 & $0.53^{\mathrm{a}}$ & 0.69 & 1.11 & $1.44^{\mathrm{a}}$ \\
\hline IFGTBC3 & $0.60^{\mathrm{bc}}$ & 0.71 & 1.29 & $1.70^{\mathrm{c}}$ \\
\hline IFGTBC4 & $0.59^{\mathrm{bc}}$ & 0.70 & 1.21 & $1.62^{\mathrm{bc}}$ \\
\hline IFGTBC5 & $0.54^{\mathrm{ab}}$ & 0.71 & 1.30 & $1.66^{\mathrm{bc}}$ \\
\hline IFGTBC6 & $0.64^{\mathrm{cd}}$ & 0.73 & 1.30 & $1.59^{\mathrm{ba}}$ \\
\hline IFGTBC8 & $0.60^{\mathrm{c}}$ & 0.75 & 1.26 & $1.79^{\mathrm{d}}$ \\
\hline IFGTBC10 & $0.65^{\mathrm{d}}$ & 0.73 & 1.33 & $1.71^{\mathrm{cd}}$ \\
\hline IFGTBC12 & $0.57^{\mathrm{ab}}$ & 0.68 & 1.27 & $1.43^{\mathrm{a}}$ \\
\hline IFGTBC14 & $0.56^{\mathrm{ab}}$ & 0.68 & 1.28 & $1.67^{\mathrm{bc}}$ \\
\hline IFGTBC16 & $0.58^{\mathrm{ab}}$ & 0.70 & 1.22 & $1.52^{\mathrm{a}}$ \\
\hline Mean & $\mathbf{0 . 5 9}$ & $\mathbf{0 . 7 1}$ & $\mathbf{1 . 2 6}$ & $\mathbf{1 . 6 1}$ \\
\hline SEm $\mathbf{( \pm )}$ & $\mathbf{0 . 0 1}$ & $\mathbf{0 . 0 2}$ & $\mathbf{0 . 0 6}$ & $\mathbf{0 . 0 3}$ \\
\hline CD @ 5\% & $\mathbf{0 . 0 5}$ & $\mathbf{N S}$ & $\mathbf{N S}$ & $\mathbf{0 . 0 9}$ \\
\hline
\end{tabular}

Figures with similar letter/alphabet as superscript do not differ significantly *CD- Critical Difference

*MAP- Months After Planting

Table.5 Volume index of Melia dubia clones at different intervals after planting

\begin{tabular}{|c|c|c|c|c|}
\hline \multirow{2}{*}{ Clones } & \multicolumn{4}{|c|}{ Volume index $\left.\mathbf{( c m}^{\mathbf{3}}\right)$} \\
\cline { 2 - 5 } & $\begin{array}{c}\text { At the time of } \\
\text { planting }\end{array}$ & $\mathbf{3}$ MAP & $\mathbf{6}$ MAP & $\mathbf{9}$ MAP \\
\hline IFGTBC1 & $9.56^{\mathrm{a}}$ & $17.06^{\mathrm{a}}$ & 71.03 & $416.90^{\mathrm{a}}$ \\
\hline IFGTBC3 & $14.26^{\mathrm{bc}}$ & $21.01^{\mathrm{ab}}$ & 108.74 & $593.22^{\mathrm{c}}$ \\
\hline IFGTBC4 & $11.55^{\mathrm{ab}}$ & $16.66^{\mathrm{a}}$ & 90.08 & $473.44^{\mathrm{ab}}$ \\
\hline IFGTBC5 & $9.58^{\mathrm{a}}$ & $18.54^{\mathrm{ab}}$ & 112.20 & $506.97^{\mathrm{abc}}$ \\
\hline IFGTBC6 & $17.73^{\mathrm{de}}$ & $23.14^{\mathrm{bc}}$ & 121.79 & $494.33^{\mathrm{ab}}$ \\
\hline IFGTBC8 & $15.70^{\mathrm{cd}}$ & $27.07^{\mathrm{c}}$ & 123.31 & $753.63^{\mathrm{d}}$ \\
\hline IFGTBC10 & $20.17^{\mathrm{e}}$ & $26.29^{\mathrm{c}}$ & 113.72 & $799.70^{\mathrm{d}}$ \\
\hline IFGTBC12 & $11.20^{\mathrm{ab}}$ & $16.38^{\mathrm{a}}$ & 112.95 & $405.87^{\mathrm{a}}$ \\
\hline IFGTBC14 & $10.20^{\mathrm{a}}$ & $16.35^{\mathrm{a}}$ & 109.81 & $539.26^{\mathrm{bc}}$ \\
\hline IFGTBC16 & $10.15^{\mathrm{a}}$ & $15.59^{\mathrm{a}}$ & 90.22 & $480.24^{\mathrm{ab}}$ \\
\hline Mean & $\mathbf{1 3 . 0 1}$ & $\mathbf{1 9 . 8 1}$ & $\mathbf{1 0 5 . 3 9}$ & $\mathbf{5 4 6 . 3 5 6}$ \\
\hline SEm $\mathbf{( \pm )}$ & $\mathbf{1 . 1 0}$ & $\mathbf{1 . 6 9}$ & $\mathbf{1 5 . 7 0}$ & $\mathbf{3 1 . 7 5}$ \\
\hline CD @5\% & $\mathbf{3 . 1 6}$ & $\mathbf{4 . 8 5}$ & $\mathbf{N S}$ & $\mathbf{9 1 . 0 6}$ \\
\hline
\end{tabular}

Figures with similar letter/alphabet as superscript do not differ significantly *CD- Critical Difference

*MAP- Months after Planting 
Fig.1 View of the experimental plot at different time intervals

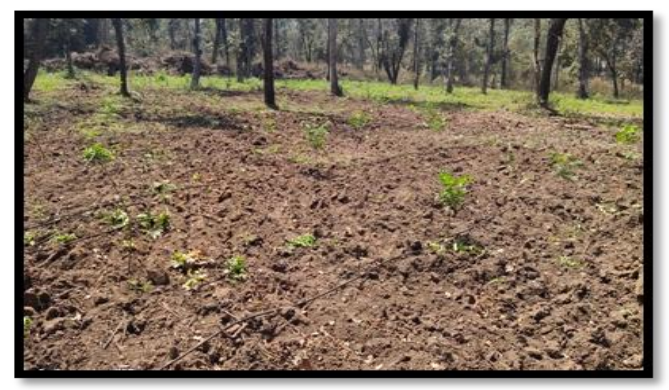

View of the experimental plot three months after planting

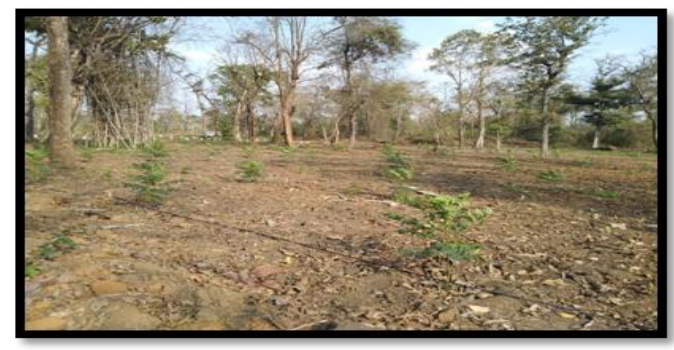

View of the experimental plot six months after planting

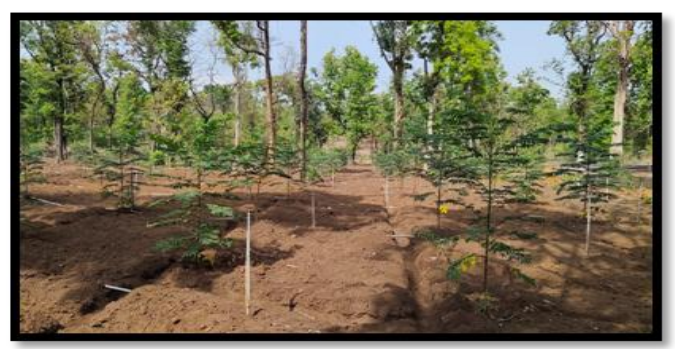

View of the experimental plot nine months after planting

Six months after planting clones did not differ significantly, relatively higher value was recorded in IFGTBC8 $\left(123.31 \mathrm{~cm}^{3}\right)$, and least value was observed in IFGTBC1 $\left(71.03 \mathrm{~cm}^{3}\right)$. Nine months after planting maximum value for volume index was recorded in IFGTBC10 $\left(799.70 \mathrm{~cm}^{3}\right)$, where as clone IFGTBC12 $\left(405.87 \mathrm{~cm}^{3}\right)$ recorded the minimum value.

Growth performance of clones in relation to quantitative traits viz., total height and collar diameter of different clones at different time intervals were recorded (at the time of planting, three months, six months and nine months after planting). Significant differences were recorded for different traits among the clones. The detailed discussion about those particular growth traits is mentioned under the following headings.

\section{Total height}

The most common measurement of primary growth is plant height. In the present study, total height was recorded up to nine months growth period with three months interval. 
Significant differences were observed for total height among the different clones at a different time interval. Similar studies were conducted by Sharma et al., (2019b) they found significant variation in height growth of 17 improved genotypes on Melia dubia in Forest Research Institute, Dehradun. Srivastav et al., (2018) conducted a study on the early performance of 19 Eucalyptus clones in Uttar Pradesh, significant variation in height growth was recorded which is comparable to present study and inferred that variation in height growth might be due to clonal difference and genetic variation. However, in the initial years, variation in height might be attributed to the influence of environment on the clones (Thakur et al., 2019) in Populous deltoids clones, Himachal Pradesh.

\section{Collar diameter}

Collar diameter is the important growth parameter. Collar diameter was recorded for different clones found significant at the time of planting and nine months after planting and non-significant at three months and six months after planting. Among the different clones, IFGTBC8 had superior significant collar diameter $(1.79 \mathrm{~cm})$ which is on par with the IFGTBC10. IFGTBC1 had significantly lower collar diameter $(1.44 \mathrm{~cm})$ (Fig 5).

The results are in agreement with study conducted by Sharma et al., (2018) on initial growth performance of Melia dubia clones in Neri, Himachal Pradesh. Significant variation was recorded among the different clones for collar diameter with a highest value of 11.50 $\mathrm{mm}$ in clone 241 , which is comparable to the present study.

In the present study, significant variation was recorded for collar diameter at the time of planting and nine months after planting may be due to genetic variation of clones and suitable microclimatic condition. At a period of three months and nine months after planting collar diameter of clones did not differed significantly may be due to the unsuitable climatic conditions.

\section{Volume index}

Volume index was analysed for different clones at different time intervals. The derived volume index for different clones was found to be significant at the time of planting, three months after planting and after nine months of planting. After six months of planting, the volume index for different clones did not differed significantly. Among the different clones, IFGTBC10 showed prominent growth with a Volume index $\left(799.70 \mathrm{~cm}^{3}\right)$, which is on par with IFGTBC8 with a volume index of $753.63 \mathrm{~cm}^{3}$. Significantly lower volume index was recorded in IFGTBC1 $\left(416.90 \mathrm{~cm}^{3}\right)$ (Fig 6). A similar study was reported by Deve and Parthiban (2014) on Dalbergia sissoo Roxb. clones, volume index of clones at six months after planting ranged from $652.41 \mathrm{~cm}^{3}$ to $103.09 \mathrm{~cm}^{3}$.

In the present study, the volume index of clones differed significantly may be due to the genetic variation of clones. clones recorded good volume index due to suitable climatic and edaphic condition of the study site. Six months after planting volume index of clones did not differed significantly may due to no rainfall at that time and due to high temperature.

\section{Acknowledgement}

The authors sincerely thank the University of Agricultural and Horticultural Sciences, Shivamogga for this opportunity. We thank the College of Forestry, Ponnampet for providing technical support and suggestions during the research period. 


\section{References}

Bagalunga: Melia dubia Cav., towering with purposes. Canopy International, 18:9-12.

Deve, D.K.R. and Parthiban, K.T., 2014, Growth performance and variability of Dalbergia sissoo Roxb. clones. Electronic Journal of Plant Breeding, $5(2): 317-321$.

Early performance of Eucalyptus clones in Vindhyan Region of Uttar Pradesh, India. International Journal of Advance Research, Ideas and Innovations in Technology, 4(2):549-552.

Langenberger, G., Marohn, C., Martin, K., Sauerborn, J. AND

Mandang, Y. I. and Artistien, S., 2004, Wood anatomy and fibre quality of utap-utap (Aromadendron elegans BI.) and seven other lesser known wood species. Buletin-Penelitian-Hasil-Hutan, 21(2):111-127.

Nasayao, E.E., Nasayao, L.Z., Zara, M.A. and Ulep, E.V. 1993,

Parthiban, K.T., Bharathi, A.K., Seenivasan, R., Kamala, K. and Rao, M.G., 2009, Integrating Melia dubia in agroforestry farms as an alternate pulpwood species. Asia-Pacific Agroforestry Newsletter, 34:3-4.

Prasad, J.V.N.S., Gangaiah, B., Kundu, S., Korwar, G.R., Venkateswarlu, B. and Singh, V.P., 2009, Potential of short rotation woody crops for pulp fiber production from arable lands in India. Ind. J. Agron., 54:380-394.

Sharma, D., Kumar, A., Thakur, S. and Sagar, N., 2018, Initial growth performance of improved genotypes of Melia dubia in low hills of Himachal Pradesh. Int. J. Chem. Stu., 6(6):1847-1849.

Sharma, D., Sharma, K., Jha, S. and Kumar, A., 2019b, Genotypic Growth Performance Evaluation of Malabar Neem (Melia Dubia) in Low Hills of Himachal Pradesh. International journal of tropical agriculture, 37(1):27-30.

Srivastav, A., Tomar, A., Yadav, A., SD, S. and Agrawal, Y., 2018,

Suprapti, S., Djarwanto, and Hudiansyah 2004, The resistance of five wood species against several wood destroying fungi. $J$. Peneli. Hasil Hutan, 22(4):239-246.

Thakur, S., Thakur, S. and Jha, S.K., 2019, First year growth variation in some selected clones of Populus deltoides in Himachal Pradesh. Journal of Pharmacognosy and Phytochemistry. 8(1):1040-1042.

Thakur, S., Thakur, S. and Jha, S.K., 2019, First year growth variation in some selected clones of Populus deltoides in Himachal Pradesh. Journal of Pharmacognosy and Phytochemistry., 8(1):1040-1042.

Tilakaratna, D., 1991, Pretreatment for the seed of Lunumidella (Melia dubiaCav.). Sri Lanka Forester, 20:27-28.

Wider, M., 2005, Land rehabilitation in the tropics with indigenous tree species: economical and ecological consideration and research needs. In: Proceeding of the Conference on International Agricultural Research for Development, Oct.11-13, 2005.

\section{How to cite this article:}

Nayana, H., Ashok B. Divatar, V. Maheswarappa, G. N. Hosagoudar and Ganapathi. 2021. Assessment of Early Growth Performance of Melia dubia Cav. Clones. Int.J.Curr.Microbiol.App.Sci. 10(01): 3488-3495. doi: https://doi.org/10.20546/ijcmas.2021.1001.411 